\title{
Комплексний підхід у реабілітації дітей дошкільного віку з логоневрозом
}

\author{
Васильєва Н. О. \\ Херсонський державний університет, м. Херсон, Україна
}

Актуальність. Відомо, що логоневроз - це руховий невротичний розлад, який характеризується порушенням плавності, темпу і ритму мовлення. Дана патологія досить поширена серед осіб дитячого віку.

Процес становлення мовленнєвої поведінки - складний за структурною і функціональною організацією (Wada J., 1975; Levy J., 1977; Андріанов О. С., 1999; Боголєпова I. Н., 1999, 2000, 2001, та ін.). Аналіз літературних джерел 3 проблеми, що стосується формування електричної активності мозку дітей, показує, що ступінь функціональної зрілості різних структур мозку на ключових етапах індивідуального розвитку має доволі значні розбіжності.

Матеріали та методи. При застосуванні методів і засобів фізичної реабілітації при логоневрозі у дітей дошкільного віку обов'язково необхідно враховувати індивідуальні особливості розвитку даної категорії дітей. Особливо це стосується дослідження стану діяльності мозкових структур, що забезпечують формування мовлення дитини. До таких методів можна віднести електроенцефалографію (ЕЕГ) - метод реєстрації електричної активності головного мозку за допомогою системи комп'ютерної електроенцефалографії у стані функціонального спокою та 3 використанням функціональних проб - відкривання очей, ритмічної фотостимуляції, гіпервентиляційної проби.

Науковцями було встановлено, що дозрівання мозку виявляється в зміні характерис- тик фонової ЕЕГ (Shafer V. L., 2011). 3 віком закономірних змін зазнають також реакція активації (зміна патерну ЕЕГ при відкриванні очей), феномен засвоєння ритмів світлових миготінь і ЕЕГ-реакція на гіпервентиляцію (Кисельников А. О., 2004; Рожкова Л. О., 2008). Аналіз даних показав, що врахування індивідуальних особливостей електричної активності і кількісна оцінка динаміки ЕЕГ в умовах застосування функціональних навантажень дозволяють значно підвищити надійність та інформативність нейрофізіологічних досліджень.

У попередніх наших дослідженнях за допомогою методу ЕЕГ було встановлено, що результати функціональних ЕЕГ-тестів вказують на знижену реактивність і функціональну недостатність активуючої системи стовбура головного мозку та недостатній гальмівний вплив кори на підкіркові структури. Це виявляється у недостатній відповіді на світлову активацію у дітей дошкільного віку з логоневрозом. У дітей з різними темпоритмічними характеристиками мовлення встановлено краще засвоєння повільних ритмів, що лежать у межах тета-діапазону ЕЕГ, а також ритмів середньої частоти, які відносяться до частот альфа-діапазону. Виявлено високу чутливість головного мозку до гіпокапнії і відносну незрілість кіркових структур головного мозку дітей дошкільного віку з різними темпоритмічними характеристиками мовлення, що проявляється підвищенням характеру частотно-амплі- 
тудних показників ЕЕГ на гіпервентиляційну пробу.

Результати дослідження та їх обговорення. Отримані електроенцефалографічні дані дали поштовх для подальшого пошуку ефективних реабілітаційних заходів при логоневрозі у дітей. Реабілітацію при логоневрозі потрібно розпочинати рано і комплексно. Фахівці, які займаються проблемою подолання логоневрозу у дітей дошкільного віку, висловлюють думку про застосування мультидисциплінарного підходу при подоланні даного порушення мовлення. Оскільки дана проблема $є$ комплексною, то до реабілітаційного процесу необхідно включати різних спеціалістів. Ефективність реабілітаційних заходів залежить від злагодженої роботи фахівців мультидисциплінарної команди, а саме:

- невролога;

- фізичного терапевта;

- дефектолога;

- логотерапевта;

- спеціального психолога.

Фізична терапія дітей дошкільного віку з логоневрозом включає в себе: лікувальний масаж, дихальні вправи, гімнастику, музичну ритміку, рефлексотерапію та фізіотерапевтичні процедури (електрофорез на комірцеву зону із седативними засобами, ванни 3 азотом, бромом та йодом, електросон-терапію).

Отже, застосування фізичних вправ при подоланні логоневрозу у дітей дошкільного віку визначається в зміні таких основних показників:

1. Відбувається покращення загального фізичного розвитку дітей даної категорії порівняно 3 їх однолітками, які не отримують фізіотерапевтичного лікування в комплексі. Це реалізується шляхом застосування гімнастичних вправ статичного характеру.

2. Помітне підвищення моторики дітей 3 логоневрозом при виконанні фізичних вправ.

Позивний вплив лікування фізичними факторами при логоневрозі у дітей має фізіологічне підгрунтя, оскільки вони допомагають стабілізувати роботу нервової системи, заспокоюють дітей та покращують їх психоемоційний стан.

Ключові слова: фізична реабілітація, логоневроз, електроенцефалографія. 